\title{
Hepatitis B Infection among Patients Attending a Sexually Transmitted Diseases Clinic in Rio de Janeiro, Brazil
}

\author{
Ledy HS Oliveira $^{+}$, Isabel R Silva, Brunno LS Xavier, Silvia MB Cavalcanti
}

\author{
Departamento de Microbiologia e Parasitologia, Instituto Biomédico, Universidade Federal Fluminense, \\ Rua Prof. Ernani Melo 101, 24210 Niterói, RJ, Brasil
}

\begin{abstract}
Hepatitis $B$ virus (HBV) has a low endemicity in Rio de Janeiro, Brazil. Sexual transmission must play an important role in this virus, but the prevalence and risk factors have never been properly investigated. The aim of this paper is to determine the prevalence and risk factors for HBV infection in patients attending a Sexually Transmitted Diseases Clinic of the Universidade Federal Fluminense, from the State of Rio de Janeiro, Brazil. In a retrospective study, HBV seroprevalence was investigated in 440 patients. Serum of each patient was assayed for antibodies against hepatitis B core antigen (anti$H B c$ ), hepatitis B surface antigen ( $H B s A g)$ and antibodies against hepatitis $B$ surface antigen (anti$H B s)$. Demographic and risk factor data were extracted from clinic notes. The overall seroprevalence of exposure markers for $\mathrm{HBV}$ (anti-HBc, $\mathrm{HBs} \mathrm{Ag}$ and anti-HBs) were 13\%, 3.4\% and $8.5 \%$ respectively. Homo/bisexual behaviour, anal intercourse, HIV infection, positive serology for syphilis and blood transfusion were predictors of the HBV exposure. Among demographic data, age and place of birth were associated with the anti-HBc seropositivity.
\end{abstract}

Key words: hepatitis B - seroprevalence - sexual transmission

Hepatitis B virus (HBV) is a common worldwide infection, committing over 2 billion of the individuals alive today at some stage of their lives (Davey 1996). The virus is found in high concentrations in blood, serum, and wound exudate; in moderate concentrations in semen, vaginal secretions, and saliva; and in low concentrations in urine, sweat, tears, and breast milk. The predominant routes of transmission vary according to the endemicity of HBV infection. In areas of low endemicity the sexual contact is the major route of transmission. Extensive studies regarding HBV sexual transmission have been conducted in low HBV endemic countries (Struve et al. 1993, Gilson et al. 1998). Heterosexuals who have unsafe sex with multiple partners and homo/bisexual men are the high-risk groups for sexual transmission (Margolis et al. 1991).

Brazilian Southeast has been recently categorized as low HBV endemic area (Martelli et al. 1999). Rio de Janeiro, a state within Southeast region, has an overall hepatitis $B$ surface antigen (HBsAg) prevalence about $2 \%$ in general population (Nogueira et al. 1990, Vanderborght et al. 1993). Most of adult infected may have acquired

\footnotetext{
${ }^{+}$Corresponding author. Fax: + 55-24-620.5266. E-mail: mipledy@ centroin.com.br Received 22 August 2000 Accepted 16 February 2001
}

the virus by sexual route but risk factors for this way has not been properly evaluated. Screening for hepatitis B in sexual transmission diseases (STD) clinics is not considered as routine procedure. Reports with adolescents (Raffaelli et al. 1993, Porto et al. 1994), pregnant women (Duarte et al. 1997) and women attending a STD clinic (Miranda et al. 1999) have provided information about sexual transmission of hepatitis B in Brazil, but extensive studies with patients attending STD clinics are still incomplete.

The aim of this study is to provide epidemiological data regarding association of sexual transmission of $\mathrm{HBV}$ and risk factors among patients attending a STD clinic from the State of Rio de Janeiro, Brazil.

\section{MATERIALS AND METHODS}

Participants - A retrospective study was developed with 440 patients attending the STD Clinic at Universidade Federal Fluminense, State of Rio de Janeiro, Brazil, over April to December in 1997. Demographic data (sex, age, pl0 -1 of birth, ethnic origin, civil status, education, and socio-economic conditions) and risk factors for HBV infection (sexual behaviour, oral or anal intercourse, sexual partners, drug abuse (intravenous or not), current and past STD history, syphilis seropositivity, HIV infection and past history 1 of blood transfusion) were extracted from the clinical notes. Blood sample was taken of each patient at the time of the attending STD clinic. 
Test methods - Sera samples were tested for total antibodies to hepatitis B core antigen (anti-HBc), hepatitis B surface antigen (HBsAg) and antibodies to HBsAg (anti-HBs) by enzyme immunoassay (Organon Tecnika) according manufacture's instructions. Samples were considered positive if the test was repeatable reactive.

Statistical analysis - Data were analysed using EPINFO 6.04 (Center for Disease Control and Prevention, Atlanta, GA, EUA, 1997) statistical software package. Odds ratio were presented with $95 \%$ confidence intervals (CI). The Chi-squared test assessed the significance between variables and serological status. Probability values less than 0,05 were considered significant.

\section{RESULTS}

Demographic finds - The sample comprised 243 females and 197 males with age range 14-72 years, average: 29 years $(\mathrm{SD}=9.1)$.

Most of the patients (80\%) were from the State of Rio de Janeiro (352/440). Among them, 53.4\% (235/440) were white, $19.5 \%$ (86/440) had black, origin and 27\% (119/440) were mulattos. The analysis of the relationships status revealed that $43.2 \%$ (190/440) were single, $46.8 \%$ (206/440) were married or had stable partner, $8.2 \%$ (36/440) were divorce and $1.6 \%$ (7/440) were widower. Considering the education level, 1.8\% (8/440) were illiterates; $56.5 \%$ (249/440) had elementary school (completed or not); 31.1\% (137/440) had high school (completed or not); and 9.7\% (43/440) had college (completed or not). At the time of the survey, $28.2 \%(125 / 440)$ earned up till one or two living wages, $36.5 \%(161 / 440)$ earned from 3 to 5 living wages, $16.1 \%$ (71/440), earned from 6 to 10 living wages and 6.5\% (29/440) earned up 10 living wages. One living wage is about 80 dollars. Eight $(1.8 \%)$ of the patients were fired.

Specific data - Among the patients, $95.4 \%$ related to have heterosexual life stile (177 males and 246 females) and $3.6 \%$ (15 males and one female) were homo/bisexual. However, $10.5 \%$ of the patients (39 males and 7 females) reported past homosexual relation. Oral and anal sex was a common practice in $41.6 \%$ (183/440) and 28.8\% (127/ 440 ) of the patients, respectively. In relation to partnerships, 64.8\% (285/440) had exclusive partner, $13.6 \%(60 / 440)$ had stable but not exclusive partner, 6.4\% (28/440) had multiple partners, and $13 \%$ (57/440) were single. Past STD partners were related by $33.3 \%$ (85/440) of the people.

Of the patients attending, $71.3 \%(314 / 440)$ had clinic symptoms of STD (syphilis, gonorrhoea, chlamydia, HPV infection, herpes, trichomonas, candidiasis). The attending motives of the remaining people were climaterium, STD partner's, rape,
HIV serology, gynaecologic, colposcopic and peniscopic exam. Seven patients $(1.6 \%)$ reported hepatitis episode and $5.7 \%$ (25/440) were submitted to blood transfusion in the past. Drugs were used by $13.5 \%$ (59/440) of the patients. After routine blood test, $1.6 \%(7 / 440)$ of the patients were found HIV seropositive and 14.1\% (62/440) were syphilis seropositive.

Serologic results - Anti-HBc marker was found in $13 \%$ (57/440), HBsAg in $3.4 \%(15 / 440)$ and anti-HBs in $8.5 \%(37 / 440)$ of the subjects. The HBsAg prevalence was $2.4 \%(6 / 243)$ in women, $3.9 \%(7 / 176)$ in heterosexual men and $6.6 \%$ $(1 / 15)$ in homo/bisexual men. Among anti-HBc seropositive individuals, $8.3 \%$ acquired immunity to HBV.

The overall prevalence of the exposure to HBV infection can be estimated from the prevalence of anti-HBc in serum. HBV infection and demographic variables are given in the Table I. The anti$\mathrm{HBc}$ prevalence was associated with age and place of birth. The highest anti-HBc seropositivity was found in the 40-44 years old age group (OR 3.96 CI 1.54-9.57, $\mathrm{p}<0.05)$. The anti-HBc prevalence showed to be lower in the patients born in the State of Rio de Janeiro than in the group born outside.

Positive anti-HBc status and specific data are showed in the Table II. The HBV prevalence was significantly higher in homo/bisexual men than in heterosexual men $(\mathrm{OR}=5.71$, CI 1.24-25.48, $\mathrm{p}<0.05)$ or in women $(\mathrm{OR}=4.17 \mathrm{CI} 1.20-14.5$, $\mathrm{p}<0.05)$. A similar trend was observed in patients with past homosexual behaviour. Among the sexual practices, anti-HBc positivity was affected by anal intercourse $(\mathrm{OR}=3.54, \mathrm{CI} 1.92-6.55, \mathrm{p}<0.05)$. Although clinic symptoms of STD were not significant for anti-HBc positivity, this marker was associated with HIV infection (OR=5.11, CI 0.8827.97, $\mathrm{p}<0.05)$ and syphilis seropositivity $(\mathrm{OR}=2.01$, CI $0.95-4.20, \mathrm{p}=0.05)$. Drug users (injecting or not) had higher anti-HBc positivity than non drug users $(\mathrm{OR}=1.89$, CI 0.87-4.04), but this finding was not significant

We have also found a significant association between anti-HBc positivity and blood transfusion $(\mathrm{OR}=2.84, \mathrm{CI} 1.01-7.73, \mathrm{p}<0.05)$. This association was independent of the sex related risk factors.

\section{DISCUSSION}

This study discloses information about demographic characteristics and sexual behaviour of individuals attending at a public STD clinic from the State of Rio de Janeiro. In our study we have detected a highly increase in hepatitis B seroprevalence among patients older than 20 years old. This finding is compatible with the fact that sexual activity is a major route of $\mathrm{HBV}$ transmission. 
Place of birth was also strongly associated to HBV infection. People who had born outside the State of Rio de Janeiro presented a significative rate of HBV prevalence. Most of these patients were from rural cities of the northeastern and probably had migrated under economic deprivation. Infectious diseases are a major concern to this condition. Although Silveira et al. (1999) has showed an association of higher seroprevalence with lower socio-economic status in Brazil, we did not find statistical significance between anti-HBc seropositivity and familiar income.
It is well established that the epidemiology of HBV infection varies greatly according to geographic, demographic and risks factors. In areas of low and intermediate endemicity the sexual transmission plays an important role on the spray of the infection (Struve et al. 1993, Heng et al. 1995). Multiple sexual partners, sexual behaviour, anal intercourse, syphilis and other sexual diseases are consistent data to attribute the sexual hepatitis B acquisition (Schereeder et al. 1982, Rosemblum et al. 1990). The HBV positive patients attended in the STD clinic were constituted as an heteroge-

\section{TABLE I}

Analysis of demographic characteristics according to anti-HBc prevalence among 440 subjects attending a sexually transmitted diseases clinic, State of Rio de Janeiro, Brazil

\begin{tabular}{|c|c|c|c|c|c|c|}
\hline & $\mathrm{N}$ & anti-HBc & $\%$ & Crude OR & $95 \% \mathrm{CI}$ & p-value \\
\hline \multicolumn{7}{|l|}{ Sex } \\
\hline Female & 243 & 29 & 11.9 & 1.0 & & \\
\hline Male & 197 & 28 & 14.2 & 1.0 & $0.43-1.43$ & 0.47 \\
\hline \multicolumn{7}{|l|}{ Age group } \\
\hline$<20$ & 68 & 6 & 8.8 & 0.61 & $0.20-1.51$ & \\
\hline $20-24$ & 107 & 8 & 7.4 & 0.47 & $0.20-1.07$ & \\
\hline $25-29$ & 98 & 16 & 16.3 & 1.43 & $0.73-2.79$ & \\
\hline $30-35$ & 58 & 8 & 13.7 & 1.06 & $0.44-2.50$ & \\
\hline $35-39$ & 41 & 4 & 9.7 & 0.67 & $0.19-1.46$ & \\
\hline $40-44$ & 29 & 10 & 34.4 & 3.96 & $1.54-9.57$ & 0.007 \\
\hline$>44$ & 39 & 4 & 10.2 & 0.78 & $0.19-2.23$ & \\
\hline \multicolumn{7}{|l|}{ From Rio de Janeiro } \\
\hline Yes & 352 & 45 & 12.7 & 0.34 & $0.08-0.49$ & \\
\hline No & 28 & 12 & 42.8 & 6.12 & $2.46-14.71$ & 0.0008 \\
\hline \multicolumn{7}{|l|}{ Ethnic origin } \\
\hline White & 235 & 30 & 12.7 & 0.96 & $0.53-1.76$ & \\
\hline Black & 86 & 11 & 12.7 & 0.98 & $0.44-2.04$ & \\
\hline Mulattos & 119 & 16 & 13.4 & 1.08 & $0.55-2.01$ & 0.98 \\
\hline \multicolumn{7}{|l|}{ Civil status } \\
\hline Single & 190 & 25 & 13.1 & 1.03 & $0.56-1.87$ & \\
\hline Married & 206 & 23 & 11.1 & 0.74 & $0.40-1.35$ & \\
\hline Divorcee & 36 & 6 & 16.6 & 1.38 & $0.45-3.60$ & \\
\hline Widower & 7 & 3 & 42.8 & 5.26 & $0.75-31.84$ & 0.08 \\
\hline Unknown & 1 & 0 & 0 & & & \\
\hline \multicolumn{7}{|l|}{ Education level } \\
\hline Illiterate & 8 & 1 & 12.5 & 0.96 & $0.02-7.70$ & \\
\hline Elementary school & 249 & 36 & 14.4 & 1.34 & $0.66-2.63$ & \\
\hline High school & 137 & 16 & 11.6 & 0.85 & $0.33-1.38$ & \\
\hline College & 43 & 4 & 9.3 & 0.65 & $0.07-2.25$ & 0.84 \\
\hline \multicolumn{7}{|l|}{ Familiar income $^{a}$} \\
\hline $1-2$ & 125 & 24 & 19.2 & 1.58 & $0.85-2.89$ & \\
\hline $3-5$ & 161 & 15 & 9.3 & 0.58 & $0.29-1.11$ & \\
\hline $6-10$ & 71 & 10 & 14.0 & 1.12 & $0.48-2.41$ & \\
\hline$>10$ & 29 & 3 & 10.3 & 0.76 & $0.14-2.62$ & \\
\hline Fired & 8 & 1 & 12.5 & 0.96 & $0.02-7.70$ & \\
\hline Unknown & 53 & 4 & 7.5 & 0.13 & $0.51-1.49$ & 0.35 \\
\hline
\end{tabular}

a: number of minimum salaries (U\$ 80 each) received per month; N: normal; HBc: hepatitis B core; OR: odd ratio; CI: confidence interval 
neous group having significative frequency of these indicators. The findings suggest sexual route of $\mathrm{HBV}$ in these patients based on association between hepatitis B, HIV and syphilis. There was no further association between HBV markers and multiple sexual partners or others STD diseases.
Although the heterosexual transmission of $\mathrm{HBV}$ is related as more frequently than homosexual transmission (Alter 1990, Duarte 1992), recent studies in STD clinics (Stroffolini et al. 1997, Gilson et al. 1998) showed the opposite. In answering about homosexual behaviour, $3.6 \%$ of the

TABLE II

Analysis of risk factors associated with HBV infection among 440 subjects attending a sexually transmitted diseases clinic, State of Rio de Janeiro, Brazil

\begin{tabular}{|c|c|c|c|c|c|c|}
\hline & $\mathrm{N}$ & anti-HBc & $\%$ & Crude OR & $95 \% \mathrm{CI}$ & p-value \\
\hline \multicolumn{7}{|l|}{ Sexual behaviour } \\
\hline Heterosexual & 423 & 50 & 11.8 & 0.19 & $0.06-0.62$ & \\
\hline Homo/bisexual & 16 & 6 & 37.5 & 5.71 & $1.24-25.48$ & 0.03 \\
\hline Unknown & 0 & 1 & & & & \\
\hline \multicolumn{7}{|l|}{ Past homosexual } \\
\hline Yes & 46 & 12 & 26 & & & 0.009 \\
\hline No & 368 & 44 & 11.9 & & & \\
\hline Unknown & 26 & 1 & 3 & & & \\
\hline \multicolumn{7}{|l|}{ Oral intercourse } \\
\hline Yes & 183 & 21 & 11.4 & 0.80 & $0.42-1.46$ & \\
\hline No & 247 & 36 & 14.5 & 0.76 & $0.41-1.40$ & 0.42 \\
\hline Unknown & 10 & 0 & & & & \\
\hline \multicolumn{7}{|l|}{ Anal intercourse } \\
\hline Yes & 127 & 31 & 24.4 & 3.54 & $1.92-6.55$ & 0.0014 \\
\hline No & 299 & 25 & 8.3 & 0.31 & $0.17-0.57$ & \\
\hline Unknown & 14 & 1 & 7.1 & & & \\
\hline \multicolumn{7}{|l|}{ Sexual partners } \\
\hline Exclusive & 285 & 34 & 11.9 & 0.87 & $0.47-1.65$ & \\
\hline Not exclusive & 60 & 9 & 15.0 & 1.22 & $0.50-2.71$ & \\
\hline Multiple & 28 & 5 & 17.8 & 1.51 & $0.43-4.29$ & \\
\hline Single & 57 & 7 & 12.2 & 0.93 & $0.34-2.22$ & \\
\hline Unknown & 10 & 2 & 20.0 & & & 0.81 \\
\hline \multicolumn{7}{|l|}{ Past STD } \\
\hline Yes & 148 & 21 & 14.1 & 1.4 & $0.61-2.13$ & 0.76 \\
\hline No & 285 & 36 & 12.6 & 0.92 & $0.50-1.73$ & \\
\hline \multicolumn{7}{|l|}{ Clinic STD history } \\
\hline Yes & 314 & 45 & 14.3 & 1.59 & $0.78-3.30$ & 0.22 \\
\hline No & 126 & 12 & 9.5 & 0.63 & $0.29-1.27$ & \\
\hline \multicolumn{7}{|l|}{ Blood transfusion } \\
\hline Yes & 25 & 7 & 28.0 & 2.84 & $1.01-7.73$ & 0.04 \\
\hline No & 415 & 50 & 12.0 & 0.35 & $0.13-1.05$ & \\
\hline \multicolumn{7}{|l|}{ Drug users } \\
\hline Yes & 59 & 12 & 20.3 & 1.89 & $0.87-4.04$ & 0.07 \\
\hline No & 378 & 45 & 11.9 & 0.56 & $0.27-1.255$ & \\
\hline Unknown & 3 & 0 & & & & \\
\hline \multicolumn{7}{|l|}{ HIV infection } \\
\hline Yes & 7 & 3 & 42.8 & 5.11 & $0.88-27.97$ & 0.04 \\
\hline No & 423 & 53 & 12.5 & 0.47 & $0.14-2.04$ & \\
\hline Unknown & 10 & 1 & 10.0 & & & \\
\hline \multicolumn{7}{|l|}{ Syphilis infection } \\
\hline Yes & 62 & 13 & 20.9 & 2.01 & $0.95-4.20$ & 0.05 \\
\hline No & 378 & 44 & 11.6 & 0.50 & $0.24-1.08$ & \\
\hline
\end{tabular}

N: normal; HBc: hepatitis B core; OR: odd ratio; CI: confidence interval 
sample related to be homo/bisexual. In a recent survey, $2.5 \%$ of the Brazilian people have homosexual practices (Ministério da Saúde 2000). However, $10.5 \%$ of the our sample related homosexual habits in the past. The degree of uncertainty in answering questions about sexual preferences may affect the assess of the investigation. Our dates are according to the last papers. HBV prevalence was at least three times more frequently in homo/ bisexuals than in heterosexuals.

Among the recorded markers, HBsAg positivity is considered as current HBV infection. The STD patients had a higher proportion HBsAg marker when compared to the local estimates. According to Martelli et al. (1999), the Southeast region present a $0.9 \%$ rate for $\mathrm{HBsAg}$. The rate of HBsAg positivity remained high in subset of women $(2.4 \%)$, heterosexual men $(3.9 \%)$ and homo/bisexual men (6.6\%). According Blumberg (1990), males exposed to HBV becomes HBsAg carries easier than females. Although not significative, among STD patients the HBsAg frequency was two times higher for male carriers. We also found a significant dependency between $\mathrm{HBsAg}$ status and HIV seropositivity $(\mathrm{p}<0.05)$.

Patients blood transfused had significative association with anti-HBc marker. These patients have not reported other risk factors. Although blood control in the State of Rio de Janeiro is considered efficient, Martelli et al (1999) have already pointed out that a residual risk of transfusion hepatitis B is still present in Brazil and other South American countries. Six out of seven patients anti$\mathrm{HBc}$ positive became immune to virus and one, HBsAg carrier.

Most of information of HBV prevalence in Brazil is available from blood donors and interviews does not included questions about sexual behaviour. The results of this investigation contribute to trace the sexual route of HBV in our state. Therefore, HBV infection could be prevented through the STD control activities. Besides, the HBsAg prevalence detected in this population is up to above the recommended for vaccination by WHO (1988). Hence, patients attending STD clinics should be routinely screened in order to identify HBV exposure and those found seronegative should be advised to be vaccinated.

\section{ACKNOWLEDGMENTS}

To the Laboratório de Hepatites Virais, Instituto Oswaldo Cruz, for the kits to detect the HBV serological markers and to Dr Nubia K Almeida, Statistical Department, UFF, for statistical treatment assistance.

\section{REFERENCES}

Alter MJ 1990. Heterosexual activity: a leading risk factor in the transmission of hepatitis B. In P Plot, FE
Andre (eds), Hepatitis B: a Sexually Transmitted Disease in Heterosexuals, Excerpta Medica, Amsterdam, p. 17-22.

Blumberg B S 1990. Sex-related aspects of hepatitis B infection and its consequences. In P Plot, FE Andre (ed), Hepatitis B: a Sexually Transmitted Disease in Heterosexuals, Exerpta Medica, Amsterdam, p. 105.

Davey S 1996. State of the Word Vaccines and Immunization, Word Health Organization, Geneva, p. 76-82.

Duarte G 1992. Doenças sexualmente transmissíveis durante o ciclo grávido-puerperal. In EN Morais, Temas de Obstetrícia, Roca, São Paulo, p. 385-406.

Duarte G, Muss-Pinhata MM, Lemos C, Quintana SM, Paschioni MC, Motta MSF 1997. Hepatite B e gravidez. Rev Bras Ginecol Obstet 19: 653-663.

Gilson RJ, de Ruiter A, Waite J, Ross E, Loveday C, Howell DR, Tedder RS, Weller IV 1998. Hepatitis $B$ virus infection in patients attending a genitourinary medicine clinic: risk factors and vaccine coverage. Sex Transm Infect 74: 110-115.

Heng BH, Goh KT, Chan R, Chew SK, Doraisingham S, Quek GH 1995. Prevalence of hepatitis B virus (HVB) infection in Singapore men with sexually transmitted diseases and HIV infection: role of sexual transmission in a city state with $\mathrm{HBV}$ intermediate endemicity. J Epidemiol Community Health 49: 309313.

Margolis HS, Alter MJ, Hadler SC 1991. Hepatitis B: involving epidemiology and implication for control. Semin Liver Dis 11: 84-92.

Martelli CMT, Turchi MD, Souto FJD, Sáez-Alquezar A, Andrade ALSS, Zicker F 1999. Anti-Abc testing for blood donations in areas with intermediate hepatitis B endemicity. Rev Pan Am Public Health 6: 6973.

Miranda AEB, Nogueira EG, Ribeiro ES, Areal KR, Alves MC 1999. Soroprevalência de HbsAg positivo em mulheres atendidas em clínica de doenças sexualmente transmissíveis. J Bras Doenças Sex Transm 11: 2-25.

Ministério da Saúde 2000. Comportamento Sexual da População Brasileira e Percepções do HIV/AIDS, Ministério da Saúde, Brasília, 73 pp.

Nogueira CMJ, Coelho VC, Ferreira HSM Leite NC 1990. Avaliação dos resultados de marcadores virais da hepatite em doadores de sangue do Hospital Universitário Clementino Fraga Filho (UFRJ). An Cong Soc Bra Hematol 12: 107.

Porto SOB, Cardoso DDP, Queiroz DAO, Rosa H, Andrade ALSS, Zicker F, Martelli CMT 1994. Prevalence and risk factors for $\mathrm{HBV}$ infection among street young in Central Brazil. J Adolesc Health 15: 577-581.

Raffaelli M, Campos R, Merritt AP 1993. Sexual practices and attitudes of street youth in Belo Horizonte, Brazil. Soc Sci Med 37: 661-670.

Rosemblum LS, Hadler SC, Castro KG, Lieb S, Jaffe H W 1990. Heterosexual transmission of hepatitis B virus in Belle Glade, Florida. J Infect Dis 161: 407-411.

Schreeder MT, Thompson SE, Hadler SC 1982. Hepatitis B in homosexual men: prevalence of infection 
and factors related to transmission J Infect Dis 146: 7-15.

Silveira T, Fonseca JC, Rivera L, Fay OH, Tapia R, Santos JL, Urdeneta E, Clemens SAC 1999. Hepatitis B seroprevalence in Latin America. Rev Panam Salud Publ 6: 378-383.

Stroffolini T, Corona R, Giglio A, Gentil G, Caprilli F, Prignano G, Tosti ME, Pasquini P, Mele A 1997. Risk factors for hepatitis B virus infection among homosexual men attending a sexually transmitted diseases clinic in Italy. $N$ Microbiol 20: 333-338.

Struve J, Kall K, Stendhal P, Scalia-Tomba G Giesecke
J, Wriland O 1993. Prevalence of hepatitis B virus markers among intravenous drugs abusers, in Stockholm: impact of heterosexual transmission. Scand J Infect Dis 25: 8-13.

Vanderborght BOM, Reis AMM, Rouzere CD, Salgado da Silva R, Yoshida CFT, Franco LGP, Maertens G, Van Heuveswijn, Pereira JM, 1993. Prevalence of anti-hepatitis $\mathrm{C}$ virus in the blood donor population of Rio de Janeiro. Vox Sang 65: 122-125.

WHO-World Health Organization 1988. WHO progress in the control of viral hepatitis: memorandum from a WHO meeting, Geneva, p. 443-455. 